\title{
The Effectiveness of Realistic Mathematics Learning Model Based on Mandailing Culture in Teaching of Students' Mathematical Problem Solving Ability
}

\author{
Marzuki Ahmad \\ Mathematics Education \\ South Tapanuli Educations Institute \\ Padangsidimpuan, Indonesia \\ Marzuki.ahmad45@yahoo.com
}

\author{
Yulia Pratiwi Siregar \\ Mathematics Education \\ South Tapanuli Educations Institute \\ Padangsidimpuan, Indonesia \\ Yuliapratiwisiregar@ rocket.mail.com
}

\author{
Nisah Ayu Siregar \\ Mathematics Education \\ South Tapanuli Educations Institute \\ Padangsidimpuan, Indonesia \\ Nisahayu28@gmail.com
}

\begin{abstract}
The purpose of this research was to know the effectiveness of realistic mathematics learning model implementation based on Mandailing culture by teaching of students' mathematical problem solving ability in junior high school. The type of research was development research used 4D model, they were define, design, develop, and disseminate. This research discussed the develop phase, it was about the effectiveness of realistic mathematics learning model implementation based on Mandailing culture. The effectiveness of learning model was reviewed from the achievement of students' mastery learning in mathematical problem solving ability, the students' learning active activities and the students' response in learning. The research was conducted in public junior high school 1 Kotanopan grade VII where the design was pretest posttest control group design. The method of data collecting was conducted using test, observation and questionnaire. The obtained data was processed using quantitative descriptive analysis. The conducted research obtained some results, they were; (1) The mastery of students' mathematical problem solving ability in experimental class through the posttest achieved $90.63 \%$, while in control class achieved $81.25 \%$ where the school classical mastery was $80 \%$; (2) The active activities in experimental class through 10 activity aspects that was observed at all fulfilled the limit of effectiveness tolerance while in control class through 8 activity aspects that was observed fulfilled the limit of assigned effectiveness tolerance; (3) The students' positive response to learning in experimental class was about $98.91 \%$ and in control class was about $83.05 \%$. If it was reviewed from the achievement criterion of learning mastery, learning active activities and students' response in experimental and control class was fulfill the criterion of the effectiveness and the effectiveness of experimental class was better than the control class. Therefore, generally states that the implementation of realistic mathematics learning model based on Mandailing culture was effective in teaching of students' mathematical problem solving ability.
\end{abstract}

Keywords-Learning Effectiveness, Realistic Mathematics, Problem Solving, Mandailing Culture

\section{INTRODUCTION}

Education has a very important role in the era of global competition. Education desperately needs to get a complex attention along with its development and growth in improving the better living standard of human. Education is one form of manifestation of dynamic human culture and full of development [1]. Humans will be educated their skills and life skills through learning so that they can survive in the current era of global competition. Getting a good learning course requires a good activity in the conducted learning activities. The standard of learning process in education process according to Government Regulation of Indonesia Republic reveals that the learning process in the education unit was interactive, inspirational, fun, challenging, motivating students to actively participate and providing sufficient space for initiative, creativity, and independence in line with the development of physical and psychological, talents, interests of students [2]. Thus teaching and learning activities that are held should be done effectively on every subject contained in the learning curriculum.

One of the goals of mathematics as one of the subjects taught from the level of primary school education, high school and college education is to form the ability to think in solving various problems. In the content standards for primary and secondary education units, Regulation of the Minister of National Education mentioned that the subjects of mathematics need to be given to all learners ranging from elementary school to equip learners with logical, analytical, systematic, critical, and creative skills as well as the ability to work together [3]. Thus mathematics is very important and a focus in improving the ability of students in solving a faced problems daily. So the way how to teach students to mathematics is not enough by introducing definitions, giving exercises to measure their abilities.

The observation of researcher (on April 12 ${ }^{\text {th }}$ 2017) in Public Junior High School 1 Kotanopan, most students have low ability in math lessons. The low of students' math learning outcomes can be seen from the students' math problem solving ability. From 32 students who took the diagnostic test of mathematical problem solving ability, the average value of students' mathematical problem solving ability was 61.32 . based on the data analysis the students' value through the minimum mastery criterion was 76 then $32 \%$ students were complete in learning activities while $68 \%$ students were not complete in learning. Based on the information that obtained by researcher from interviews with mathematics teacher and also as the principal of Public Junior High School 1 Kotanopan (Mr. I.H, S.Pd.), the researcher concluded that: Students' learning motivation is less, learning activities tend to be one-way and less involving students' activities, the way of student learning is 
memorized, students are less able to apply learned concepts to problem solving, students tend to be bored in teaching and learning activities.

Based on information from the implementation of preliminary observation, it can be understood that learning is still conventional in need of new paradigms that are more appropriate to the natural way of students in learning mathematics increase students' activity in learning activities. In addition, new innovations are required in the implementation of learning by linking the local culture in the implementation of learning that can make students feel close to the subject matter, learning is more meaningful and on the students' self embedded that learning and mathematics is a self culture that gives a positive impact on the love of students against learning and teaching activities and mathematics.

The problem solving ability is a very important math skill to be mastered by students. Problem solving is a human activity that combines the concepts and rules that have been obtained previously, not as a generic skill[4]. In this case the problem solving ability will be increased when doing problem solving activities to new problems. Problem solving is an important part of learning activities. Reveals 10 problem solving strategies that can be used as the basis of teaching approach, namely: (a) Working backwards; (b) Finding a pattern; (c) Take a different point of view; (d) Solving a problem that is analogous to the facing problem but simpler; (e) Consider the extreme cases; (f) Creating an image (visual representation); (g) Suspect and test by reason; (h) Considering all possibilities (listing / comprehensive inclusion); (i) Organize data; (j) Logical reasoning [5]. Next, Newel and Simon state that general problem solving involves three main steps which include presenting the problem, setting goals and objectives and starting to solve problems and using the means-ends analysis to assess progress and if necessary redefine the objectives [6]. The process of problem solving which was done according to Gagne there are 5 parts, they are: (a) Presents the problem in a clearer form; (b) Stating the problem in a form that can be solved; (c) Develop alternative hypotheses and work procedures which is thought to be good using for problem solving (d) Test the hypothesis and do the solution to get the result; (e) Reexamine whether the obtained results are true, or may choose the best solution alternative [7].

Improve the students' mathematical problem solving ability need to develop the skills to understand the problem, create mathematical models, solve problems, and interpret the solution [8]. According to Polya solution for problem solving contains 4 stages of completion, namely: (a) Understand the problem; students are required to understand the problem; (b) Make a plan of solving; students think about and consider the plan of the solution that must be done; (c) Carry out a solution plan; students carry out a planned plan of solutions and then check each step by step in problem solving (d) Check the problem solving results; students test the steps that have been done [9].

The new paradigm of education is now more emphasis on learners as human beings who have the potential to learn and grow. This new paradigm demands that teachers no longer be a source of information but as a learning motivator. Students are seen as being active and have the ability to build their own knowledge. Through the new paradigm is expected students are active in learning, discussing, daring to convey ideas and accept opinions of others. To support the learning process in accordance with the changes and objectives of mathematics education, it needs a breakthrough that is focused on the application in everyday life (contextual). In addition must be adjusted to the cognitive level of students, as well as the use of integrated evaluation methods in the learning process is not just a test at the end of learning.

Realistic mathematics learning that refers to Realistic Mathematics Education (RME) was first introduced and developed in Netherlands in 1970 by a group of mathematicians from the Freudenthal Institute, Uterecht University in Netherlands. Stated that RME is developed under the basic principles, namely (1) Guided Reinvention and Progressive Mathematization; (2) Didactical Phenomenology; and (3) Self-developed Models [10]. Further characteristics of Realistic Mathematics Educations (RME) according to Treffers in are: (1) The use of context in learning, (2) The use of models to develop progressive mathematization, (3) Utilization of students' construction result, (4) Interactivity of teachers and students occurs, (5) Relevance of mathematical material [11].

Realistic mathematics based on Freudenthals' concept who argued that mathematics is a human activity [12, 13]. With the main idea is that students should be given the opportunity to reinvent ideas and mathematical concepts with adult guidance. Revealed the realistic mathematics education of Indonesia has the characteristics of students more actively thinking, context and teaching materials are directly related to the school environment and student, the role of teachers is more active in designing the teaching materials and classroom activities [14]. Therefore, students are not seen as passive recipients, but should be given the opportunity to rediscover ideas and mathematical concepts under the guidance of teachers. Realistic Mathematics Educations (RME) is more attention to the potential of the child or students who should be developed [15]. This rediscovery process was developed through exploration of real-world issues. The context of mathematical problems is the starting point of learning that is constructed by students to get problem solving through a mathematical process. Mathematizing is an organizing and structuring activity according to which acquired konowledge and skills are used to dicover unknow regularities, relations and structures [16]. Blum and Niss revealing the real world is everything beyond mathematics, like other lessons that are not math, daily life situations and the environment around us [17]. Every child can learn and every child sees the world through his own cultural glasses which in turn can improve student activity and achievement in learning [18]. Where problem that is displayed need to consider the socio-cultural situation contained in the learners. The removal of socio-cultural problems cannot be separated from the habitual habits found in the life of society. Thus it is necessary that the social system contained in community life is linked in the learning system in accordance with local culture.

Learning that involves the context of the real world of students in this case is how important the mathematics teachers understand the socio-cultural of children, how to interact, take advantage of the facts and cultural 
environment experienced by students and bring the social situation into mathematics learning. "tubu unte, tubu dohot durina, tubu jolma tubu dohot adatna" [19]. The phrase gives the meaning that the ancestral value found in humans that they carry from birth that has been imprinted in the heart and soul. By bringing the socio-cultural context contained in an area will provide a strong motivation for students to execute their activities. Thus the problems presented in the learning activities should be adopted from the local environment and culture. Given the problems that arise it is necessary to formulate problems that need to be abstracted into formal mathematical models to produce solutions in mathematical form and interpreted in the form of problem solutions.

Mandailing communities based on dalihan natolu hold 3 ethics of society. Three courtesy in the life of society that is respect to mora, persuasive to anak boru be careful to kahanggi (suhut) [20]. With the application of principles of dalihan natolu then the social system is based on olong (affection) will cause the society marsiolongan (love each other) which will lead to atigoran (honesty) likewise domuwill cause adomuan (unity) which will manifest adamean (peace). With the systematic of mandailing customary law with base on dalihannatolu can get mardomu tahi (consensus) the heavy will become light and which is difficult to be easy on every problem.

Mandailing culture which have a social system such as pedigree, marsialapari (mutual cooperation) happy to have a dialogue, etc. The community's customary life mandates in running its king-led government. The king with his assistant in this case provides guidance and protection to his people by admonishing dalihan natolu. Dalihan natolu literally is a three stove is a community institution of south tapanuli which is unity of suhut, anakboru dan mora [21]. Revealed that dalihan natolu is a center that consists of three components (suhut, anakboru dan mora) which constitutes a social system. And delivered also with the openness of kinship group will cause olong (affection) and domu (unity) [20]. With the love and unity it will form a force that can be used in various aspects of life. With the collaboration between mandailing cultures with RML in learning activities will instill good cultural values in learners. In addition, it can enrich the learning activities that result in increased the students' mathematical knowledge and able to maintain identity in the face of globalization.

Based on the theory of realistic mathematics learning and the theory contained in the mandailing culture, syntax of realistic mathematics learning model based on mandailing culture has 6 phases, namely: (1) Apperception of Mandailing culture; (2) Group formation and provide contextual problems to students; (3) Describes contextual problems; (4) Guided discovery by cooperation; (5) Presents and develops the work: (6) Make conclusions in accordance with mathematics material and the context of the problem. The following table presents the activities of teachers and students according to the learning phases.

The Phases ANd Teachers' BehaVior In RML BASEd On MANDAILING Culture

\begin{tabular}{|c|c|}
\hline Teachers' Activities & Students' Activities \\
\hline \multicolumn{2}{|c|}{ Step 1. Apperception of Mandailing Culture } \\
\hline $\begin{array}{l}\text { - Illustrates the mathematical problems associated with the mandailing } \\
\text { culture and shows that with the mathematical sciences can solve the } \\
\text { problems of everyday life }\end{array}$ & $\begin{array}{l}\text { - Observe the teachers' explanation in understanding the problems that } \\
\text { exist in the real world of mandailing community life and able to plan the } \\
\text { problem solving that arises in everyday life. }\end{array}$ \\
\hline $\begin{array}{l}\text { - Creating a positive apperception and motivation of learning mathematics } \\
\text { in children with a mandailingcultural approachthrough the provision of } \\
\text { advice word. }\end{array}$ & $\begin{array}{l}\text { - Respond and understand the apperception and motivation submitted by } \\
\text { the teacher }\end{array}$ \\
\hline $\begin{array}{l}\text { - Create an atmosphere of class cohesiveness with yells related to realistic } \\
\text { mathematics and mandailing culture who led by teacher. }\end{array}$ & $\begin{array}{l}\text { - Prepare self to follow the learning activities and enthusiastic to carry out } \\
\text { the yells with full compactness. }\end{array}$ \\
\hline \multicolumn{2}{|c|}{ Step 2. Group Formation and Provide Contextual Problems to Students. } \\
\hline $\begin{array}{l}\text { - Determine the composition of the division of student group members } \\
\text { consisting of 5-6 students per group. With each group consisting of } \\
\text { suhut (student 1), anakboru (student 2), mora (student 3), kahanggi } \\
\text { (student 4), pisang raut (student 5), andmora ni mora (student 6). } \\
\text { - Telling and directing students to form each study group. }\end{array}$ & $\begin{array}{l}\text { - Taking into division of groups and binding on the principles contained } \\
\text { in existing work systems and preparing self for taking positions and } \\
\text { accepting an existing division of labor. } \\
\text { - Establish groups according to the job determination who determined by } \\
\text { the teacher. }\end{array}$ \\
\hline - Giving the students' activity sheet to students 11 (suhut) of each group. & $\begin{array}{l}\text { - Each of student } 1 \text { (suhut) in the group receives a student's activity sheet } \\
\text { from the teacher. }\end{array}$ \\
\hline $\begin{array}{l}\text { - Have the suhut fill out the identity and read out the instructions on the } \\
\text { students' activity sheet }\end{array}$ & - Fill the identity contained in the students' activity sheet \\
\hline \multicolumn{2}{|c|}{ Step 3. Describes Contextual Problems } \\
\hline $\begin{array}{l}\text { - Directing students in understanding the context of the problems found on } \\
\text { the students' activity sheet }\end{array}$ & $\begin{array}{l}\text { - Pay attention to the direction of the teacher to be able to understand the } \\
\text { problems contained in the students' activity sheet. }\end{array}$ \\
\hline $\begin{array}{l}\text { - Directs one of the students (suhut) read every problem found on } \\
\text { students' activity sheets aloud for each group. }\end{array}$ & $\begin{array}{l}\text { - Student (suhut) in each group read out the problems contained on the } \\
\text { students' activity sheet and other students listen and take note and } \\
\text { further understanding by individual }\end{array}$ \\
\hline - Explain the existing cultural problems generally. & $\begin{array}{l}\text { - Pay attention to and examine teachers' explanation of culture } \\
\text { according to the existing problem. }\end{array}$ \\
\hline \multicolumn{2}{|c|}{ Step 4. Guided Discovery by Cooperation } \\
\hline $\begin{array}{l}\text { - Get students to solve the problems contained in the students' activity } \\
\text { sheet by working principle dalihannatolu. } \\
\text { - Guiding, encouraging / directing students to solve problems and } \\
\text { working on students' activity sheets that include numbers } 1,2,3 \text {. }\end{array}$ & $\begin{array}{l}\text { - Resolve the problems contained in the students' activity sheet by } \\
\text { working principle dalihannatolu. } \\
\text { Resolve the problem in an orderly manner with the provisions of } \\
\text { team } 1 \text { (anakboruandpisangraut) discuss one problem, as well as } \\
\text { team } 2 \text { (kahanggiandsuhut) and team } 3 \text { (morawithmoranimora) each } \\
\text { discussing one problem. }\end{array}$ \\
\hline $\begin{array}{l}\text { - Giving scaffolding in the formation of model-of and model-for to group } \\
\text { who occur the difficulty. }\end{array}$ & - $\quad$ Pay attention the scaffolding delivered by the teacher \\
\hline - Encourage students to expose their ideas openly. & $\begin{array}{l}\text { - Each student expresses his understanding according to the concept } \\
\text { needed in solving the problem }\end{array}$ \\
\hline $\begin{array}{l}\text { - Allow students of group members to ask questions if they do not } \\
\text { understand how to discuss the students' activity sheets }\end{array}$ & $\begin{array}{l}\text { - Ask questions to group mates or teachers if they are less able to solve } \\
\text { problems. }\end{array}$ \\
\hline - $\quad$ Assist students in problem solving to get solutions. & $\begin{array}{l}\text { - Pay attention to the teachers' help in solving the problem so as to } \\
\text { produce a good solution }\end{array}$ \\
\hline
\end{tabular}




\begin{tabular}{|c|c|}
\hline \multicolumn{2}{|c|}{ Step 5. Presents and Develops The Work } \\
\hline $\begin{array}{l}\text { - Gives an opportunity to one of the group members (anak boru) groups } \\
\text { to present the results of group discussions in front of the class } \\
\text { - Give other groups a chance to criticize / respond to the work of the } \\
\text { presenter group } \\
\text { - Provide an opportunity for other groups to present if the solving } \\
\text { technique / answering result is different with the presenter group. } \\
\text { - Controlling the course of the discussion in order the learning is } \\
\text { effective }\end{array}$ & $\begin{array}{l}\text { - Student group representatives (anak boru) present the work } \\
\text { through presentation in front of the class } \\
\text { - Delivering a debate / response to a presentation delivered by a } \\
\text { group of presenters delivered by the side of anakboru or suhut } \\
\text { - Present a presentation of group work if the problem solving method } \\
\text { used or the results obtained are different with the presentation of } \\
\text { the presenter group. } \\
\text { - With wisdom follow the learning activities in accordance with the } \\
\text { principles contained in dalihan natolu }\end{array}$ \\
\hline \multicolumn{2}{|c|}{ Step 6. Make Conclusions in Accordance with Mathematics Material and The Context of The Problem } \\
\hline $\begin{array}{l}\text { - Directs students to build mathematical concepts and principles that } \\
\text { are found in each group } \\
\text { - Telling and directing each student (mora) from each group to convey } \\
\text { the conclusions. } \\
\text { - The teacher affirms the conclusions of the material that has delivered } \\
\text { by each group. }\end{array}$ & $\begin{array}{l}\text { - Construct mathematical concepts and principles within the group } \\
\text { who based on dalihan natolu } \\
\text { - Convey the conclusions through group representatives delivered by } \\
\text { students who are located as mora } \\
\text { - Listen to and examine the affirmation of the conclusions that } \\
\text { delivered by the teacher. }\end{array}$ \\
\hline
\end{tabular}

Realistic Mathematics Learning Model Based on Mandailing Culture is the result of modification or collaboration of Realistic Mathematics Learning with mandailing culture, it means that all the principles that is contained in realistic mathematics learning is applied in the Realistic Mathematics Learning Model Based on Mandailing Culture by involving aspects of local culture in each model components. The implementation of Realistic Mathematics Learning Model Based on Mandailing Cultureis a mathematics learning model based on constructivist views that pay attention to the characteristics of mathematics and mandailing cultural values. Therefore, the researcher considers it important to describe the effectiveness of the Realistic Mathematics Learning Model Based on Mandailing Culture.

\section{RESEARCH METHODS}

This research was the development research with 4-D model. Which includes the define stages, design stages, develop stages, and disseminate stages [22]. In the stages of development research conducted the product testing phase in the form of field trials to students of Public Junior Hogh School 1 Kotanopan. Design pretest-posttest control group design used to know the difference of treatment effectiveness shown in the experimental group with the control group [23]. Thus used research design as Pretest-Posttest Control Group $x=$ The treatment used realistic mathematics learning model based on mandailing culture

$0_{1}=$ Pretest value (before being treated)

$\mathrm{O}_{2}=$ Posttest value (after being treated)

The variables in this research are grouped into three variables, namely: (1) Independent variable is realistic mathematics learning model based on mandailing culture. (2) Dependent variable in this research is the effectiveness of the given treatment. Effectiveness variables are broken down into sub variables as follows: (a) Students' Mathematics problem solving ability that includes the ability to understand the problem, plan the solutions, make a solutions and make a conclusion (b) Students' activity in the learning is the whole series of students' activities during the learning process that includes the initial activities, core activities, and final activities. (c) Students' responses are students' responses or opinions about the feelings of likes / dislikes to the model of learning component, feel new or not new to the learning component, students' opinions to follow the next learning such as the current learning and students' opinions on the students' activity sheet.

The population of this research is all students of class VII public junior high school 1 kotanopan academic year

The Mastery Of Students' Mathematical Problem Solving Ability

\begin{tabular}{|c|c|c|c|c|c|c|c|c|}
\hline \multirow{3}{*}{ Mastery } & \multicolumn{4}{|c|}{ Experimental Class } & \multicolumn{4}{|c|}{ Control Class } \\
\hline & \multicolumn{2}{|c|}{ Pretest } & \multicolumn{2}{|c|}{ Posttest } & \multicolumn{2}{|c|}{ Pretest } & \multicolumn{2}{|c|}{ Posttest } \\
\hline & Sum & Percentage & Sum & Percentage & Sum & Percentage & Sum & Percentage \\
\hline Achieve & 5 & 15.63 & 29 & 90.63 & 5 & 15.63 & 26 & 81.25 \\
\hline Not achieve & 27 & 84.38 & 3 & 9.38 & 27 & 84.38 & 6 & 18.75 \\
\hline
\end{tabular}

Design with one kind of treatment involving 2 classes of research objects covering 1 class were used as experimental class and 1 class was designated as control class.

\begin{tabular}{|lllll|}
\hline $\mathrm{E}$ & $:$ & $\mathrm{O}_{1}$ & $\times$ & $0_{2}$ \\
$\mathrm{P}$ & $:$ & $0_{1}$ & & $0_{2}$ \\
\hline
\end{tabular}

Description:

$$
\begin{aligned}
& \mathrm{E}=\text { Symbol for Experimental Class } \\
& \mathrm{P}=\text { Symbol for Control Class }
\end{aligned}
$$

2016-2017 consisting of 5 rooms (study group). The sample selection in this research was done by random sampling technique. Where sampling is done by taking randomly to two classes as research sample and random retrieval in determining the classes used as experiments and control classes. With the sampling technique selected VII-1 class as the experiment class with the number of students 32 people and elected VII-3 class as control class with the number of students 32 people. 
The research data was collected through: (1) Test, Observation and questionnaire. The test is given to the students to obtain learning result data in the form of students' Mathematical Problem Solving Ability obtained through pretest and posttest result of the experimental class and control class. The test is tested to students in the form of essay test of 5 items; (2) The data of students' active activity in learning is obtained by using observation sheet of students' activity which was held 4 times meeting. Observation is done by an observer with the aim to get the dominant things that students do in learning activities; (3) The questionnaire data of the students' response in experimental class and control class were obtained using students' response sheets to the implementation of learning. Learning tools and research instruments used before have been validated by expert in order to obtain content suitability, format, illustration and language and have been tested in order to determine which instruments are suitable for use in data collection. Further data analysis technique in this research is quantitative descriptive analysis that is analysis which aims to describe mastery of students' mathematical problem solving ability, students' response, students' activity in learning activity.

\section{RESULTS AND DISCUSSION OF RESEARCH}

The effectiveness of realistic mathematics learning model based on mandailing culture implementation in teaching the mathematical problem solving ability in this research reviewed from various aspects. These aspects include students' learning mastery in Mathematical Problem Solving Abilities, students' active activities in learning and students' responses.

\section{A. Students' Mathematical Problem Solving Ability}

The students' mathematical problem solving ability obtained and analyzed through pretest and post-test in the implementation of research. This test is tested on the experimental class and control class. Data of students' mathematical problem solving ability who analyzed include students' mastery in learning in accordance with the value of the minimum mastery criterion of school is 76. Analysis of the data can be observed in the table below.

The students' learning mastery of pre-test in experimental class and control class found there are 5 students who achieve (15.63) and 2 students who haven't achieve yet $(48.38 \%)$. Furthermore after the treatment in the experimental class that is the implementation of realistic mathematics learning model based on mandailing culture through post-test obtained there were 29 students who achive (90.63\%). Furthermore, in the control class that is given learning with the usual approach or with a conventional approach through post-test obtained 26 students achieve $(81.25 \%)$. By considering the classical mastery established by the school that is equal to $80 \%$ then the classical mastery in the experimental class and control classes are met, then with the completion of classical mastery, the learning mastery in the experimental class and control class meets the criteria of effectiveness. Furthermore, with the acquisition of classical mastery in the experimental class $(90.63 \%)$ higher than classical mastery in the control class $(81.25 \%)$ then the effectiveness of learning mastery of experimental class is better than the control class. indicated that the use of Realistic Mathematics Education Approach can enhanced mathematics achievement of students. Previous research also mention that use of Realistic Mathematics Education Approach can enhanced mathematics achievement of students and the results of this study to some extent provide information that students who are taught using Realistic Mathematics approach are better than students taught by traditional approaches [24].

\section{B. Students' Activities during the Learning}

Students' activity in the learning activity is observed by an observer. Observers monitored the experimental class against a randomly selected group of five established groups. Similarly, in the control class, monitoring of selected observation objects is 5 people. Observations conducted during the learning process take place by noting the dominant activities conducted by students within a period of every 5 minutes. Observations were conducted in the 1 st to 4th minutes and the recording was done in the 5th minute. The result of observation activities can be seen in table 3 .

Based on observations result according to table 2. So in the experimental class and control class of the students' active activity is in the criteria of the limits of the effectiveness of learning except on the aspect of paying

STUDENTS' ACTIVITIES DURING THE LEARNING

\begin{tabular}{|c|c|c|c|}
\hline \multirow{2}{*}{ Category of Observation } & \multicolumn{2}{|c|}{$\begin{array}{c}\text { Activities Average in Teaching and } \\
\text { Learning Activities }(\%)\end{array}$} & \multirow{2}{*}{$\begin{array}{c}\text { The Limit Criterion } \\
\text { of the Effectiveness } \\
(\%)\end{array}$} \\
\hline & $\begin{array}{l}\text { Experimental } \\
\text { Class }\end{array}$ & Control Class & \\
\hline a. $\quad$ Read/Understand (Book/Students'Activity Sheet) & 7.55 & 7.23 & $5 \% \leq \mathrm{P} \leq 15 \%$ \\
\hline b. Pay attention to teacher explanations & 7.81 & 16.32 & $5 \% \leq \mathrm{P} \leq 15 \%$ \\
\hline c. Solve the problems & 20.57 & 17.28 & $15 \% \leq \mathrm{P} \leq 25 \%$ \\
\hline d. Ask the questions & 10.94 & 6.62 & $5 \% \leq \mathrm{P} \leq 15 \%$ \\
\hline e. Discussion between fellow students & 19.53 & 12.41 & $15 \% \leq \mathrm{P} \leq 25 \%$ \\
\hline f. Discussion between students and teachers & 9.11 & 6.63 & $0 \% \leq \mathrm{P} \leq 10 \%$ \\
\hline g. Demonstrate results / express opinions / ideas & 9.38 & 10.34 & $5 \% \leq \mathrm{P} \leq 15 \%$ \\
\hline h. Noting things that are relevant to the learning activities & 4.95 & 8.52 & $0 \% \leq \mathrm{P} \leq 10 \%$ \\
\hline i. Make the conclusions & 5.73 & 6.76 & $0 \% \leq \mathrm{P} \leq 10 \%$ \\
\hline j. $\quad$ Portfolio (Solve home work and work) & 4.43 & 7.89 & $0 \% \leq \mathrm{P} \leq 10 \%$ \\
\hline Total & 100 & 100 & \\
\hline
\end{tabular}


attention to teacher explanations and the discussion between fellow students in the control class. By considering the criteria of the effectiveness of activity in learning that $80 \%$ of the observed aspects must meet the tolerance limit of effectiveness of each aspect then the students' active activity in the experimental class and control class meet the criteria of effectiveness. However, by considering that in the experimental class $100 \%$ the observed activity is met and in the control class $80 \%$ the observed activity is met then the students' active activity on the experimental class is better than the control class. In this IRME approach students were observed three times which takes five weeks during the Mathematics class, based on IRME. Previous study showed that Mathematics activities for those who were taught using IRME are higher than for those using the conventional approach [25]. Next, data analysis of teachers and pupils' activityies carried out in the 4 learning meetings; it found that teachers activity score was 4.41 where; it was a good category. The overall activity of pupils' activities in the 10 observed sessions reached the limits of tolerance. Thus the activities of teachers and pupils in realistic cultural-based mathematics learning were fall into the effective model [26].

\section{Students' Response in Learning}

From the questionnaire responses filled by 32 students after following the learning on the topic of numbers with realistic mathematics learning models based on mandailing culture on experimental class and conventional learning model or conventional learning approach in control class, the percentage of students' response as follows.

Students' responses to learning aspects are generally within positive criteria. The average value of students' positive responses related to feelings of pleasure or displeasure to the components of subject matter, book of student, students' activity sheet/work sheet, learning atmosphere in class and the way of teacher in teaching on the experimental class achieved $99.3 \%$ and control class achieved $86.87 \%$. The average value of students' positive responses related to the new or not new feeling to the components of subject matter, book of student, students' activity sheet/work sheet, learning atmosphere in class and the way of teacher in teaching in the experimental class achieved $96.25 \%$ and control class achieved $84.37 \%$.Furthermore, the value of students' positive responses about the interest to follow further learning activities just as follow now in the experimental class was $100 \%$ and the control class was $78.12 \%$.

Furthermore, the students 'positive response to the experimental class related to understanding and interest in students' activity sheet was $100 \%$ and the students' positive response in the experimental class related to the understanding and interest on the students' work sheet was $82.81 \%$. So the total positive response of students to the learning activities in the experimental class was $98.91 \%$ and in the control class was $83.05 \%$. With effectiveness criterion used is student response fulfill criteria of effectiveness if positive response of student $\geq 85 \%$ then the students 'positive responses to the experimental class are met and the students' response to the control class is not met. Furthermore it can be stated students' response on experimental class was better than control class. Previous the results of this research proves that Realistic Mathematics Education approach is effective on the ability of students' mathematical concept understanding [27]. Next, findings showed that the student-centered learning based on local culture model and the instrument for higher order mathematical thinking ability are valid and effective to use in teaching mathematics for junior high school [28].

\section{CONCLUSION}

The conclusions that can be obtained from the results and discussion of research was the realistic mathematics learning based on mandailing culture was effective to teach students' mathematics problem solving ability in the topic of number in class VII junior high school. This is indicated by: (1) The mastery of students' mathematical problem solving abilities who are given learning with a realistic mathematics learning model based on mandailing culture or in an experimental class meets the criteria of effectiveness and better than the conventional learning model or control class; (2) The students' active activity in the experimental class meets the criteria of effectiveness, and the effectiveness was better than the control class; (3) The students' response to learning in the experimental class was positive and better than the control class.

The suggestions of researchers in relation to the research that has been done is as follows: (1) In the learning of mathematics as much as possible so that the teacher use the realistic mathematics learning approach based on mandailing culture so that student is more active and the process of learning becomes more fun for student and the learning of mathematics becomes meaningful for student. (2) The results of research with realistic mathematics learning to teach students' mathematical problem solving ability can be one alternative for researchers especially research from mathematics education to conduct further research.

\section{ACKNOWLEDGMENT}

The author would like to thank the Incentive Program of National Innovation System Research of Ministry of Research, Technology and Higher Education who has provided funds in Individual Research in the field of social humanities in the reference theme of socio-cultural development of the implementation year 2018.

\section{REFERENCES}

[1] Trianto, Mendesain Model Pembelajaran Inovatif-Progesif:Konsep, Landasan, dan Implementasinya Pada Kurikulum Tingkat Satuan Pendidikan (KTSP), Jakarta : Kencana Prenada Media Group, 2011.

[2] Peraturan Pemerintah Republik Indonesia Perubahan atas Peraturan Pemerintah Nomor 19 Tahun 2005 Tentang Standar Nasional Pendidikan, No. 32. 2013.

[3] Permendiknas. Peraturan Menteri Pendidikan Nasional No. 22 tentang Standar Isi, 2006.

[4] R.W. Dahar, Teori-Teori Belajar, Jakarta: Erlangga, 1989.

[5] Wahyudin, Peranan Problem Solving. Proceeding National Seminar on Science and Mathematics Education, the Role of IT/ICT in Supporting the Implementation of Competensy-Based Curriculum, Bandung: JICA-IMSTEP, 2003.

[6] M. E. Gredler, Learning and Instructions: Teori dan Aplikasi Edisi keenam. Jakarta: Kencana, 2011.

[7] Ruseffendi. E.T., Pengantar Kepada Membantu Guru mengembangkan Kompetensinya dalam Pengajaran Matematika untuk Meningkatkan CBSA, Bandung: Tarsito, 1991.

[8] Y. S. Sugiman dan Kusumah, Dampak Pendidikan Matematika Realistik Terhadap Peningkatan Kemampuan Pemecahan Masalah Siswa SMP. IndoMS. J.M.E Vol.1 No. 1, pp. 41-51, 2010. http:chromeextension://ngpampappnmepgilojfohadhhmbhlaek/captured.html?bac $\mathrm{k}=1$ 
[9] G. Polya, How to Solve it $\left(2^{\text {nd }} e d\right)$. Princeton, NJ: Princeton University Press, 1973.

[10] K. Gravemeijer, Developing Realistic Mathematics Education. Utrecht: CD- $\beta$ Press, 1994.

[11] A. Wijaya, Pendidikan Matematika Realistik Alternatif Pendekatan Pembelajaran Matematika, Yogyakarta: Graha Ilmu. 2012.

[12] H. Freudenthal, Geometry between the devil and the deep sea. Educational Studies in Mathematics, 3, pp. 413-435, 1971.

[13] H. Freudenthal, Mathematics as an educational task, Dordrecht, The Netherlands: Reidel. 1973.

[14] R.K. Sembiring, Pendidikan Matematika Realistik Indonesia (PMRI): Perkembangan dan Tantangannya, IndoMS. J.M.E Vol.1 No. 1, pp. 11-16, 2010.

https://www.neliti.com/publications/63611/pendidikanmatematika-realistik-indonesia-pmri-perkembangan-dantantangannya

[15] R. Soedjadi, Inti Dasar - Dasar Pendidikan Matematika Realistik Indonesia. Jurnal Pendidikan Matematika, Volume 1, NO.2, 2007. http://ejournal.unsri.ac.id/index.php/jpm/article/download/807/221

[16] J. D. Lange, Mathematics Insight and Meaning, Utrecht: OW \& OC, 1987.

[17] S. Hadi, Pendidikan Matematika Realistik; Teori, Pengembangan, dan Implementasinya, Jakarta: Rajawali Pers, 2016.

[18] R. I. Arends, Learning To Teach Seventh Edition, New York: McGraw Hill Companies, 2007.

[19] P. Nasution, Adat Budaya Mandaliling dalam Tantangan Zaman, Medan: Forkala Sum. Utara, 2005.

[20] Z. P. Lubis, Kumpulan Catatan Lepas Tentang Mandailing, Medan: Pustaka Widyasarana, 2010.

[21] S. Lubis, Adat Hangoluan Mandailing, Medan:Pengarang, 1997.

[22] Thiagarajan, S. dkk., Intructional development for training teachers of exceptional children: A sourcebook. Minnesota: Central for Innovation on Teaching the Handicaped, 1974. http://files.eric.ed.gov/fulltext/ED090725.pdf

[23] S. Arikunto, Manajemen Penelitian. Jakarta: Rineka Cipta, 2009.

[24] E. Zakaria, M. Syamaun, The Effect of Realistic Mathematics Education Approach on Students' Achievement And Attitudes Towards Mathematics. Mathematics Education Trends and Research 2017 No.1 pp. 32-40, 2017.

http://www.ispacs.com/journals/metr/2017/metr-00093/article.pdf

[25] A. Veloo, C. M. Zubainur, How A Realistic Mathematics Educational Approach Affect Students' Activities In Primary Schools?. Procedia Social and Behavioral Sciences 159 pp. $309-313,2014$. https://www.sciencedirect.com/science/article/pii/S187704281406508 2

[26] M. Ahmad, Y. P. Siregar, N. A. Siregar and H. Effendi, Realistic Math-Based Learning Model Based on Mandailing Culture. International Journal of Sciences: Basic and Applied Research (IJSBAR) Volume 39, No 1, pp. $67-78,2018$.

http://gssrr.org/index.php?journal=JournalOfBasicAndApplied\&page $=$ article\&op=view $\&$ path $\% 5 \mathrm{~B} \% 5 \mathrm{D}=8501$

[27] L. Lestaria, E. Surya, The Effectiveness of Realistic Mathematics Education Approach on Ability of Students' Mathematical Concept Understanding. International Journal of Sciences: Basic and Applied Research (IJSBAR) Vol. 34, No 1, pp. 91-100, 2017.

http://gssrr.org/index.php?journal=JournalOfBasicAndApplied\&page $=$ article \&op=view $\&$ path $\% 5 \mathrm{~B} \% 5 \mathrm{D}=7545 \&$ path $\% 5 \mathrm{~B} \% 5 \mathrm{D}=3511$

[28] S. Saragih, E. E. Napitupulu and A. Fauzi, Developing Learning Model Based on Local Culture and Instrument for Mathematical Higher Order Thinking Ability. International Education Studies; Vol. 10, No. 6, 2017.

https://files.eric.ed.gov/fulltext/EJ1144619.pdf 